\title{
P65 Targets FGFR1 to Regulate the Survival of Ovarian Granulosa Cells
}

\author{
Xiaolong Yuan ${ }^{1,+}{ }^{+}$Zhonghui $\mathrm{Li}^{1,2,+}$, Yaru Kong ${ }^{1}$, Yuyi Zhong ${ }^{1}{ }^{\mathbb{D}}$, Yingting He ${ }^{1}$, Ailing Zhang ${ }^{3}$, \\ Xiaofeng Zhou ${ }^{1}$, Yao Jiang ${ }^{1}$, Zhe Zhang ${ }^{1}{ }^{\circledR}$, Hao Zhang ${ }^{1, *}$ and Jiaqi $\mathrm{Li}^{1, *}$ \\ 1 National Engineering Research Center for Swine Breeding Industry, Guangdong Provincial Key Lab of \\ Agro-Animal Genomics and Molecular Breeding, College of Animal Science, South China Agricultural \\ University, Guangzhou 510642, China; yxl@scau.edu.cn (X.Y.); lizh_scau@163.com (Z.L.); \\ yrkong@yeah.net (Y.K.); yyzhong04@163.com (Y.Z.); 15521059247@163.com (Y.H.); zxf93715@163.com (X.Z.); \\ jyao192@163.com (Y.J.); zhezhang@scau.edu.cn (Z.Z.) \\ 2 Institute of Animal Biotechnology, Xinjiang Academy of Animal Science, Urumqi 830000, China \\ 3 College of Biology and Food Engineering/Development, Center of Applied Ecology and Ecological \\ Engineering in Universities, Guangdong University of Education, Guangzhou 510303, China; \\ zhangailing@gdei.edu.cn \\ * Correspondence: zhanghao@scau.edu.cn (H.Z.); jqli@scau.edu.cn (J.L.); Tel.: +86-020-85283495 (H.Z.); \\ $+86-020-85282016$ (J.L.) \\ + These authors contributed equally to this work.
}

Received: 19 September 2019; Accepted: 25 October 2019; Published: 29 October 2019

\begin{abstract}
In female mammals, the abnormal apoptosis of ovarian granulosa cells (GCs) impairs follicular development and causes reproductive dysfunction. Many studies have indicated that the FGFR1 gene of the PI3K signaling pathway and the p65 subunit of the transcription factor NF- $\mathrm{kB}$ may regulate the proliferation and apoptosis of GCs involved in follicular development. However, little is known about whether p65 regulates the transcription of FGFR1, as well as the biological effects of $p 65$ and FGFR1 on the survival of GCs and follicular development. In porcine follicles and GCs, we found that $p 65$ and FGFR1 were exclusively expressed in the GCs of follicles, and the mRNA and protein levels of $p 65$ and FGFR1 significantly increased from small to large follicles. Both $p 65$ and FGFR1 were found to activate the PI3K signaling pathway, and the expressions of proliferation markers (PCNA and MKI67) and the anti-apoptotic gene BCL2 were significantly increased by $p 65$ and FGFR1. Furthermore, both $p 65$ and FGFR1 were observed to promote cell proliferation and inhibit the cell apoptosis of GCs, and p65 was confirmed to bind at the -348/-338 region of FGFR1 to positively regulate its transcription. Moreover, p65 was further found to enhance the pro-proliferation and anti-apoptotic effects of FGFR1. Taken together, p65 may target the $-348 /-338$ region of FGFR1, promote the transcription of $F G F R 1$, and enhance the pro-proliferation effect and anti-apoptotic effect of FGFR1 to facilitate the growth of follicles. This study will provide useful information for further investigations on the p65-mediated-FGFR1 signaling pathway during folliculogenesis in mammals.
\end{abstract}

Keywords: transcription factor p65; FGFR1; cell proliferation and apoptosis; ovarian granulosa cells

\section{Introduction}

In female mammals, the follicles, which consist of an oocyte surrounded by somatic cell components, i.e., granulosa cells (GCs) and theca cells [1,2] are the fundamental functional units of ovaries. The main functions of follicles are to produce mature oocytes for the propagation of the species and to synthesize the estrogens that support sexual responses [1,2]. During folliculogenesis, which includes selection, recruitment, dominance, and ovulation, the follicles dynamically progress through the primordial, primary, secondary, antral, and mature stages, with most follicles falling into 
atretic stages [1-3]. It has been widely recognized that the survival of GCs plays an important role in deciding the fate of follicles during folliculogenesis $[4,5]$. A great number of studies have shown that abnormal apoptosis of GCs impairs follicular dynamics and then causes reproductive dysfunction $[4,6]$ and polycystic ovary syndrome $[7,8]$ in humans. However, the underlying molecular mechanisms regarding the survival of GCs involved in follicular development have been largely unexplored.

Previous studies have demonstrated that the fibroblast growth factors (FGFs) are indispensable for cellular processes such as cell proliferation, cell survival, and steroidogenesis in GCs [9,10]. The FGF receptor 1 (FGFR1) gene, one of key genes of the PI3K signaling pathway, is the critically important regulator of follicular development [11,12]. In humans, loss of function of FGFR1 has been reported to induce sexual immaturity and reproductive incompetence [13,14]. In buffalo, the mRNA and protein levels of FGFR1 increase along with the growth of follicles $[9,15]$. In chickens, knockdown of the expression of FGFR1 significantly inhibits the proliferation of GCs [16] and the growth of follicles [12]. Additionally, the transcription factor p65, one of the core components of transcription factor NF- $\mathrm{kB}$, has been reported to regulate the expressions of genes involved in the survival of GCs and folliculogenesis $[17,18]$. In humans, $p 65$ has been identified to highly associate with polycystic ovary syndrome caused by the dysfunction of GCs [19]. In mice, $p 65$ promotes cell cycle entry in GCs [20]. In porcine atretic follicles caused by the excessive apoptosis of GCs, the expressions of p65 is dramatically lower than that in healthy follicles [21]. These observations suggest that FGFR1 and $p 65$ have an essential role in regulating the proliferation and apoptosis of GCs associated with follicular development.

Previously, we found that the promoter of FGFR1 harbored several putative binding sites of $\mathrm{p} 65$. Therefore, we hypothesized that p65 might control the transcription of FGFR 1 and then regulate the proliferation and apoptosis of GCs. In this study, using gilts as the biological model, the expression patterns of $p 65$ and FGFR1 during follicular development were first characterized, and then the biological effects of $p 65$ and FGFR1 on cell survival, PI3K, and the apoptosis signaling pathway were investigated. The molecular regulations between $p 65$ and FGFR1 were further identified. This study was the first report to explore the molecular relationship between $p 65$ and FGFR1 in GCs, and these works will provide new insight into the effects of $p 65$ and FGFR1 during follicular development in mammals.

\section{Materials and Methods}

\subsection{Ethics Statement}

The animal experiments were conducted according to the Regulations for the Administration of Affairs Concerning Experimental Animals (Ministry of Science and Technology, Beijing, China) and were approved by the Animal Care and Use Committer of South China Agricultural University, Guangzhou, China (Approval number: 2018B116).

\subsection{Animals and Sample Preparation}

Ovaries were collected from a single local commercial pig slaughterhouse in Guangzhou and transferred to our laboratory in phosphate-buffered saline containing penicillin $(100 \mathrm{IU} / \mathrm{mL})$ and streptomycin $(100 \mu \mathrm{g} / \mathrm{mL})$ (Invitrogen, Shanghai, China) at a storage temperature of $37^{\circ} \mathrm{C}$.

\subsection{Culture of Porcine GCs In Vitro}

The porcine ovarian GGs were cultured according to our previous studies [22,23]. Briefly, 5-7 mm follicles were punctured for the collection of GCs using a $1 \mathrm{~mL}$ syringe, and the isolated GCs were washed twice with phosphate-buffered saline preheated to $37^{\circ} \mathrm{C}$. The cells were seeded into $75 \mathrm{~cm}^{2}$ flasks and cultured at $37^{\circ} \mathrm{C}$ under $5 \% \mathrm{CO}_{2}$ in DMEM (Hyclone, Logan, UT, USA) containing $10 \%$ fetal bovine serum (Hyclone, Logan, UT, USA), $100 \mathrm{IU} / \mathrm{mL}$ penicillin, and $100 \mu \mathrm{g} / \mathrm{mL}$ streptomycin. When cells reached $80 \%$ coverage of the flask, cells were seeded into 24 well plates for further experiments. 


\subsection{Real-Time Quantitative PCR Analysis}

When cells covered $80 \%$ of one well, pcDNA3.1-FGFR1, pcDNA3.1-p65, pcDNA3.1-Basic, si-p65, si-FGFR1, and the negative siRNA control were transfected into the cells for $48 \mathrm{~h}$. At least three wells per group were collected for extraction of total RNA. The total RNA was extracted using TRIzol reagent (TaKaRa, Tokyo, Japan) and then reverse-transcribed using a PrimeScript RT Master Mix Synthesis Kit (TaKaRa, Tokyo, Japan) for mRNAs. The relative expression levels of mRNAs were quantified using Maxima SYBR Green qRT-PCR Master Mix (2×) (Thermo Scientific, Waltham, CF, UAS) in a LightCycler Real-Time PCR system (96 system, Roche Diagnostics Ltd., Basel, Switzerland). The expression level of GAPDH mRNAs was used as endogenous controls, and the fold changes were calculated using the $2^{-\Delta \Delta \mathrm{ct}}$ method. The primer sequences are listed in Table 1.

Table 1. Primers of real-time PCR (RT-PCR), chromatin immunoprecipitation (ChIP) assay, and coding sequence cloning.

\begin{tabular}{|c|c|c|c|}
\hline Name & Sequence & Product (bp) & Accession Number \\
\hline CDS-FGFR1 & $\begin{array}{l}\text { F: CGGGATCCGCTCACCAACGAGGATCAA } \\
\text { R: GCTCTAGAGTCACAGCTAAGGATGGAGT }\end{array}$ & 2597 & XM_005671767.3 \\
\hline CDS-P65 & $\begin{array}{l}\text { F: GGGGTACCATGGACGACCTCTTCCСССТ } \\
\text { R: GCTCTAGATTAGGAGCTGATCTGACTCA }\end{array}$ & 1662 & NM_001114281.1 \\
\hline ChIP-FGFR1 & $\begin{array}{l}\text { F: GACTCAGTTTAGCGCATTGC } \\
\text { R: GAGAAAAGTCCTCAGGCTCC }\end{array}$ & 92 & XM_005671767.3 \\
\hline ChIP-GAPDH & $\begin{array}{l}\text { F: GATGTCCTGAGCCCCTACAG } \\
\text { R: GGTAGGTGATGGGGACTGAG }\end{array}$ & 102 & NM_001206359.1 \\
\hline qRT-PCR-FGFR1 & $\begin{array}{l}\text { F: GGCTACAAGGTCCGTTATG } \\
\text { R: CAATCTTACTCCCATTCACC }\end{array}$ & 289 & XM_005671767.3 \\
\hline qRT-PCR-P65 & $\begin{array}{l}\text { F: CATGCGCTTCCGCTACAAG } \\
\text { R: GGTCCCGCTTCTTTACACAC }\end{array}$ & 284 & NM_001114281.1 \\
\hline qRT-PCR-GAPDH & $\begin{array}{l}\text { F: TCGGAGTGAACGGATTTG } \\
\text { R: TCACCCCATTTGATGTTGG }\end{array}$ & 250 & NM_001206359.1 \\
\hline qRT-PCR-PCNA & $\begin{array}{l}\text { F: ATGCAGACACCTTGGCACTA } \\
\text { R: TTTCCGAGTTCTCCACTTGC }\end{array}$ & 247 & NM_001291925.1 \\
\hline qRT-PCR-CASP3 & $\begin{array}{l}\text { F: AGGAGCAGTTTTATTTGCGTGC } \\
\text { R: AGTCCCACTGTCCGTCTCAA }\end{array}$ & 204 & NM_214131.1 \\
\hline qRT-PCR-GSK3B & $\begin{array}{l}\text { F: TAGTCGAGCCAAACAGACGC } \\
\text { R: ATTGGGTTCTCCTCGGACCA }\end{array}$ & 202 & NM_001128443.1 \\
\hline qRT-PCR-BAX & $\begin{array}{l}\text { F: AGCGCATTGGAGATGAACTG } \\
\text { R: AAGTAGAAAAGCGCGACCAC }\end{array}$ & 157 & XM_003127290.5 \\
\hline qRT-PCR-BCL2 & $\begin{array}{l}\text { F: TTGCCGAGATGTCCAGCCAG } \\
\text { R: TCAGTCATCCACAGGGCGAT }\end{array}$ & 202 & XM_021099593.1 \\
\hline qRT-PCR-PIK3C3 & $\begin{array}{l}\text { F: AACGGGCTTTGAGATAGTGAA } \\
\text { R: AAGTTGCTTGGTTGGTGGATA }\end{array}$ & 184 & NM_001012956.2 \\
\hline qRT-PCR-PDK1 & $\begin{array}{l}\text { F: ACATGTACTCCACTGCACCC } \\
\text { R: AGGCGTGATATGGGCAATCC }\end{array}$ & 91 & NM_001159608.1 \\
\hline qRT-PCR-FOXO3 & $\begin{array}{l}\text { F: ACAAACGGCTCACTCTGTCCCA } \\
\text { R: GAACTGTTGCTGTCGCCCTTATC }\end{array}$ & 85 & NM_001135959.1 \\
\hline qRT-PCR-TSC1 & $\begin{array}{l}\text { F: AGCCGTCGTGGAAGCATAAG } \\
\text { R: GTGCAGGTGGACGAGATAGA }\end{array}$ & 245 & XM_021070814.1 \\
\hline qRT-PCR-mTOR & $\begin{array}{l}\text { F: CCGTCATCCCCTTATCCACC } \\
\text { R: GGTCGTAGTCTGGAGCCATC }\end{array}$ & 153 & XM_003127584.6 \\
\hline qRT-PCR-MKI67 & $\begin{array}{l}\text { F: ACAACAGGAGGAGGAAGTGCT } \\
\text { R: TTGACCTAGACGCGGGGAT }\end{array}$ & 300 & XM_021073740.1 \\
\hline
\end{tabular}

\subsection{Construction of the FGFR1 5' Deletion and Luciferase Assay}

The genomic DNA of porcine ovary tissues was extracted and used as a template in this study. PCR was performed by using PrimerSTAR ${ }^{\circledR}$ (TaKaRa, Dalian, China) high fidelity enzyme to obtain the FGFR1 promoter to a length of $2445 \mathrm{bp}$. The CAAT box, TATA box, GC box, and potential binding sites of p65 were predicted using AliBaba (http://gene-regulation.com/pub/programs/alibaba2/index.html), PROMO (http://alggen.lsi.upc.es/cgi-bin/promo_v3/promo/promoinit.cgi?dirDB=TF_8.3), and TFBIND 
(http://tfbind.hgc.jp). The putative binding sites of $C / E B P \beta$ concurrently predicted by all of those four tools were used for further analysis. The primers are presented in Table 2, and the PCR products were purified by gelatinization and the addition of an " $\mathrm{A}$ " tail with products to combine with $\mathrm{pMD}-18 \mathrm{~T}$, which were transformed into competent $\mathrm{DH} 5 \alpha$ cells and were inoculated overnight on ampicillin-containing lysogeny broth plates at $37^{\circ} \mathrm{C}$. Furthermore, monoclonal bacteria bearing platelets were added to ampicillin of lysogeny broth medium to incubate overnight at $37^{\circ} \mathrm{C}$ in a shaker. The bacteria were collected by centrifugation, the plasmids were extracted, and the correct plasmid for sequencing was named T-FGFR1. T-FGFR1 was then used as a template, and seven different upstream primers were designed to amplify deletion fragments. The locations of the FGFR1 deletion fragments were: P1 (-2044/+401), P2 (-1652/+401), P3 (-1069/+401), P4 (-815/+401), P5 (-700/+401), P6 (-377/+401), and P7 (-84/+401). Each deletion fragment was identified by Sanger sequencing. The correct plasmids for each deletion fragment containing KpnI and BglII cleavage sites (Table 2) were obtained. Simultaneously, each deletion fragment was cloned into the eukaryotic expression vector pGL3-Basic, which was digested with KpnI and BgIII restriction endonucleases. According to Promega's dual luciferase reporter assay kit (Promega, Madison, WI, USA), the BioTek Synergy 2 multifunctional microplate reader (BioTek, Winooski, VT, USA) was utilized for fluorescence detection. The ratio of the expression of firefly luciferase to renilla luciferase was the target fragment activity. The putative binding sites of p65 were GGAAATTCCC/TTCCCTGGCC.

Table 2. Primers for $5^{\prime}$ deletion fragments of FGFR1 promoter.

\begin{tabular}{|c|c|c|c|}
\hline Name & Sequences & Product (bp) & Accession Number \\
\hline p1 $(-2044 /+401)$ & $\begin{array}{l}\text { F: GGGGTACCAAATTAGGGGACAAGGTTATCT } \\
\text { R: GAAGATCTGAGTTGGCGGAAAAGTTGGG }\end{array}$ & 2445 & XM_005671767.3 \\
\hline p2 $(-1652 /+401)$ & $\begin{array}{l}\text { F: GGGGTACCATAGCCTGATTCCTCAAGTCTG } \\
\text { ditto }\end{array}$ & 2053 & XM_005671767.3 \\
\hline p3 $(-1069 /+401)$ & $\begin{array}{l}\text { F: GGGGTACCGTTGCGCTGCCTGTGGTGTA } \\
\text { ditto }\end{array}$ & 1470 & XM_005671767.3 \\
\hline $\mathrm{p} 4(-815 /+401)$ & $\begin{array}{l}\text { F: GGGGTACCACTTCAGGGCTACAGCGTCT } \\
\text { ditto }\end{array}$ & 1216 & XM_005671767.3 \\
\hline p5 $(-700 /+401)$ & $\begin{array}{l}\text { F: GGGGTACCAGCCAGAACGCAGGAAAGGA } \\
\text { ditto }\end{array}$ & 1101 & XM_005671767.3 \\
\hline p6 $(-377 /+401)$ & $\begin{array}{l}\text { F: GGGGTACCGACTCAGTTTAGCGCATTGC } \\
\text { ditto }\end{array}$ & 778 & XM_005671767.3 \\
\hline p7 $(-84 /+401)$ & $\begin{array}{l}\text { F: GGGGTACCGCTTCGGCTCCATTGTTCC } \\
\text { ditto }\end{array}$ & 485 & XM_005671767.3 \\
\hline P6 deletion & $\begin{array}{l}\text { F: GGCGACCTCG }{ }^{* * * * C C G C G G G C G C G C G C T G C A T C ~} \\
\text { R: GAAGATCTGAGTTGGCGGAAAAGTTGGG }\end{array}$ & 748 & \multirow{2}{*}{ XM_005671767.3 } \\
\hline P6 deletion & $\begin{array}{l}\text { F: GGGGTACCGACTCAGTTTAGCGCATTGC } \\
\text { R: GATGCAGCGCGCGCCCGCGG****CGAGGTCGCC }\end{array}$ & 50 & \\
\hline
\end{tabular}

\subsection{Cell Transfection, Proliferation, and the Apoptosis Assay}

The coding sequences of FGFR1 (Gene ID: 100153248, Accession Number: XM_005671767.3) and p65 (Gene ID: 100135665, NM_001114281.1) were cloned into pcDNA3.1 (+) (ThermoFisher, Guangzhou, China) with the restrictive enzymes for FGFR1 (BamHI and XbaI) and p65 (KpnI and XbaI). The sequences of primers for these coding sequences are shown in Table 2. The si-p65, si-FGFR1, and their respective negative control were synthesized and purified by RiboBio Co.Ltd. (Guangzhou, China). pcDNA3.1-FGFR1, pcDNA3.1-p65, si-p65, or si-FGFR1 was transfected into GCs by using Lipofectamine $^{\mathrm{TM}} 3000$ Transfection Reagent (ThermoFisher, city, country) according to a previous study [24]. Briefly, when cells reached $70 \%$ coverage of one well, the plasmids were transfected into cells in antibiotic-free medium. The transfected cells were incubated at $37^{\circ} \mathrm{C}$ for $6 \mathrm{~h}$, after which the medium was completely replaced and the cells were maintained in culture until further treatment.

Cell proliferation assays were performed using a Cell-Light Edu Apollo 567 In Vitro Kit (RiboBio Co., Ltd., Guangzhou, China). GCs were seeded into 48 well plates one day prior to transfection. 
When the cells reached 70\% coverage of one well, pcDNA3.1-FGFR1, pcDNA3.1-p65, pcDNA3.1-basic, si-FGFR1, si-p65, or siRNA-NC were transfected into the cells at different final concentrations for $48 \mathrm{~h}$. The specific steps were: diluting the Edu solution 1: 1000 with cell culture medium to prepare $50 \mu \mathrm{M}$ Edu medium, adding $150 \mu \mathrm{L}$ of $50 \mu \mathrm{M}$ Edu medium to each well for $2 \mathrm{~h}$, discarding the culture medium, adding $150 \mu \mathrm{L}$ of cell fixing solution ( $80 \%$ acetone) to each well for $30 \mathrm{~min}$ at room temperature, washing twice with PBS, adding $150 \mu \mathrm{L}$ of penetrant (0.5\% TritonX-100 in PBS) to permeabilize the cells and rinsing once with PBS, adding $150 \mu \mathrm{L}$ of $1 \times$ Apollo staining solution, and incubating for $30 \mathrm{~min}$ at room temperature in the dark. DNA was then stained with $100 \mathrm{ng} / \mathrm{mL}$ DAPI $(150 \mu \mathrm{L} /$ well $)$ for $20 \mathrm{~min}$. Photographs of cells were taken by using a fluorescent microscope (EclipseE600, Nikon, Tokyo, Japan). All cells were stained in blue, and the cells in red were specifically proliferating and replicating. The overlays of red and green indicate the proliferation rate of target cells.

Analysis and detection of cell apoptosis were based on our previous studies [22,23]. Cell apoptosis assays were performed using an annexin V-FITC Apoptosis Detection Kit (BioVision, Milpitas, CA, USA) according to the manufacturer's instructions. Briefly, GCs $\left(1-5 \times 10^{5}\right.$ cells/well) were cultured in triplicate in 6 well plates for one day prior to transfection. When the cells reached $70 \%$ coverage of one well, the plasmids were transfected into the cells at different concentrations for $48 \mathrm{~h}$. The cells were then harvested, washed twice with ice-cold PBS, and resuspended in $500 \mu \mathrm{L}$ of binding buffer. Next, $1.25 \mu \mathrm{L}$ of annexin V-FITC was added in the dark for $15 \mathrm{~min}$ at room temperature, then $1000 \times g$ centrifugation for $5 \mathrm{~min}$ was done at room temperature to remove the supernatant. The cells were gently resuspended with $0.5 \mathrm{~mL}$ precooling $1 \times$ solution, and $10 \mu \mathrm{L}$ of PI (propidium iodide; $50 \mu \mathrm{g} / \mathrm{mL}, \mathrm{BD}$, New York, NY, USA) was added. Last, the cells were analyzed using a flow cytometer (Becton Dickinson Co., San Jose, CA, USA) using the FITC signal detector (FL1) and phycoerythrin emission signal detector (FL2). All experiments were performed at least three times. Cells in the lower right quadrant of figure are annexin-positive/PI-negative early apoptotic cells. The cells in the upper right quadrant are annexin-positive/PI-positive late apoptotic cells. Cells undergoing early and late apoptosis were identified as apoptotic cells.

\subsection{Western Blot Analysis}

The cells were harvested and analyzed for their expression levels of total p65 and FGFR1 using the anti-p65 and anti-FGFR1 antibodies (Cell Signaling Technology, Danvers, MA, USA). Protein concentrations were determined using a BCA Protein Assay Kit (Vigorous Bio-technology Beijing Co., Ltd., Beijing, China), and equal amounts of protein were separated by SDS-PAGE and electroblotted onto polyvinylidene difluoride membranes. The membranes were blocked with $5 \%$ nonfat milk in PBS containing a percentage of Tween-20 for $1 \mathrm{~h}$, and then incubated with a primary antibody against hamartin (1:1000; Biorbyt, San Francisco, CA, USA) overnight at $4{ }^{\circ} \mathrm{C}$. An anti-GAPDH antibody (1:3000; Sigma, St. Louis, MO, USA) or $\beta$-actin (1:2000; Sigma, St. Louis, MO, USA) was used as an internal control. After incubation with secondary antibodies for $1 \mathrm{~h}$ at room temperature, antibody-bound protein bands were visualized using an ECL-PLUS Kit (Amersham Biosciences, Piscataway, NJ, USA). The gray scale values of the bands were calculated using ImageJ software, which was freely downloaded from NIH. The relative protein expression levels of p65 and FGFR1 were normalized to $\beta$-Actin or GAPDH values. At least three replicates were conducted for each group.

\subsection{Chromatin Immunoprecipitation Assay}

The GCs were cross-linked when the cell density reached $80 \%$ of the wells. The original culture medium in the flask was then discarded, and the cells were sequentially treated with formaldehyde, glycine, and PBS-Halt Cocktail, and were then centrifuged to collect the cell pellet. The chromatin immunoprecipitation (ChIP) assay (Thermofisher, Rockford, IL, USA) was carried out according to the previously described ChIP protocol. The ChIP primer for the -348/-338 region of FGFR1 is presented in Table 1 and was used to detect the binding extent of p65 and polymerase II. After immunoprecipitation, 
the p65 binding site was identified by PCR amplification. Total fragmented DNA was used as the input. The DNA marker was $500 \mathrm{bp}$.

\subsection{Immunohistochemistry Assay}

The immunohistochemical localizations of $\mathrm{p} 65$ and FGFR1 were evaluated by using the primary antibodies anti-p65 and anti-FGFR1 (Cell Signaling Technology). The immunohistochemical analysis was conducted according to a previous study [25]. Briefly, the large (5-7 $\mathrm{mm})$ and small $(3-5 \mathrm{~mm})$ follicles were fixed at room temperature in $4 \%$ paraformaldehyde for $24 \mathrm{~h}$, paraffin-embedded, and then serially sectioned at $5 \mu \mathrm{m}$. After deparaffinization, antigen retrieval, and blocking in normal goat serum, the sections were incubated overnight at $4{ }^{\circ} \mathrm{C}$ in anti-p65 and anti-FGFR1 (Cell Signaling Technology, USA), and the sections were washed and incubated with biotin-labeled goat anti-rabbit secondary antibody for $30 \mathrm{~min}$. The sections were then washed and incubated with avidin-biotin-peroxidase for $10 \mathrm{~min}$ and counterstained with hematoxylin. Positive immunoreactivity was represented by dark brown straining, and negative immunoreactivity was represented by blue staining. Images were captured by using confocal microscopy (DM4000B, Leica, Wetzlar, Germany).

\subsection{Statistical Analysis}

All data are shown as mean \pm standard deviation (SD) of repeated experiments. All experiments were independently repeated at least three times. Student's t-test (two-tailed) was used to analyze the significance of mean differences in the data using $\mathrm{R}$ software (version 3.5.3). * indicates $p<0.05$; ** indicates $p<0.01$.

\section{Results}

\subsection{Expression Patterns of $p 65$ and FGFR1 in Follicles and GCs}

To explore the biological functions of $p 65$ and FGFR1 during the development of follicles, the expression patterns of $p 65$ and FGFR 1 in small (1-3 mm) and large (5-7 mm) follicles were first detected (Figure 1). In large (Figure 1A) and small (Figure 1B) follicles, the immunohistochemical results indicated that $p 65$ was likely to be exclusively expressed in GCs, as opposed to theca cells. Similar observations were made for FGFR1 in the large (Figure 1C) and small (Figure 1D) follicles. Moreover, the mRNA (Figure 1E) and protein (Figure 1F) levels of $p 65$ were significantly higher in large follicles than in small follicles $(p<0.05$ ), as were those of FGFR1 (Figure 1G,H). These results indicated that $p 65$ and FGFR1 might promote the development of follicles by affecting the function of GCs.
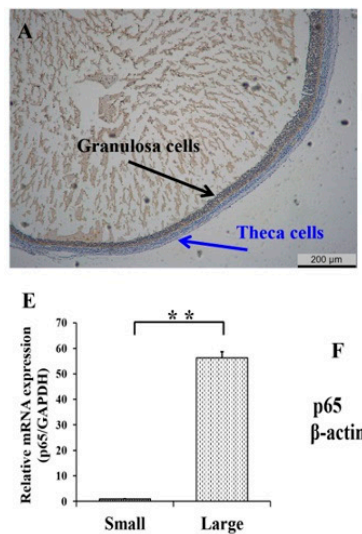
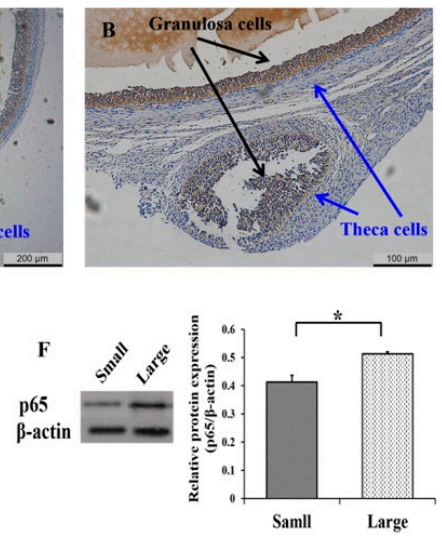
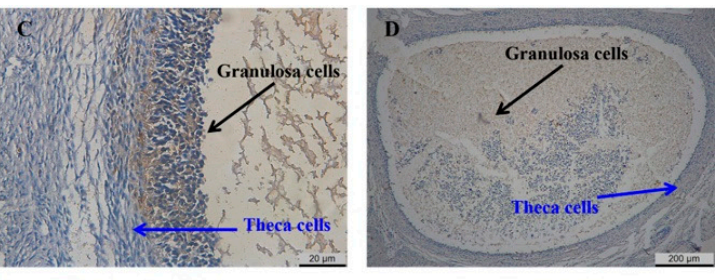

G

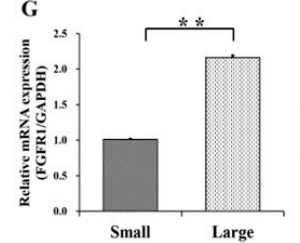

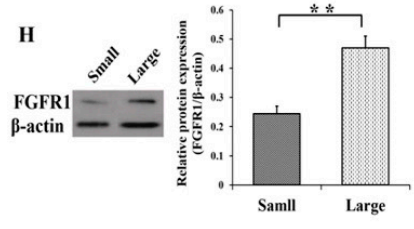

Figure 1. Expression patterns of $p 65$ and FGFR1 in follicles and granulosa cells (GCs). The representations of immunohistochemical results of p65 (A,B) and FGFR1 (C,D) in large and small follicles, respectively. The relative mRNA (E) and protein (F) levels of $p 65$ in small and large follicles. The relative mRNA (G) and protein $(\mathbf{H})$ levels of FGFR1 in small and large follicles. ${ }^{*}$ indicates $p<0.05$; ${ }^{* *}$ indicates $p<0.01$. Scale bars: $200 \mu \mathrm{m}$ for $5 \times$ figures; $100 \mu \mathrm{m}$ for $10 \times$ figures; $20 \mu \mathrm{m}$ for $20 \times$ figures. 


\subsection{Pro-Proliferation and Anti-Apoptotic Effects of p65 on GCs}

To determine the biological effects of $p 65$ on the PI3K and apoptosis signaling pathway, overexpression plasmids and small interfering RNAs (siRNAs) of $p 65$ were built. We found that the mRNA level of p65 increased with the concentration of pcDNA3.1-p65 (Figure 2A), and $200 \mathrm{ng}$ of pcDNA3.1-p65 plasmid was selected for further use. Compared to the control group (pcDNA3.1), the protein level of p65 was significantly increased by $200 \mathrm{ng}$ of pcDNA3.1-p65 (Figure 2B). The specific siRNA for p65 (si-p65) significantly inhibited the mRNA level of $p 65$ at 50, 75, and $100 \mathrm{nM}$ (Figure 2C), compared to the negative control (NC). We selected $100 \mathrm{nM}$ of si-p65 for further study on the considerations for cellular tolerance, and the protein count of p65 was significantly inhibited at $100 \mathrm{nM}$ compared to the NC group (Figure 2D).
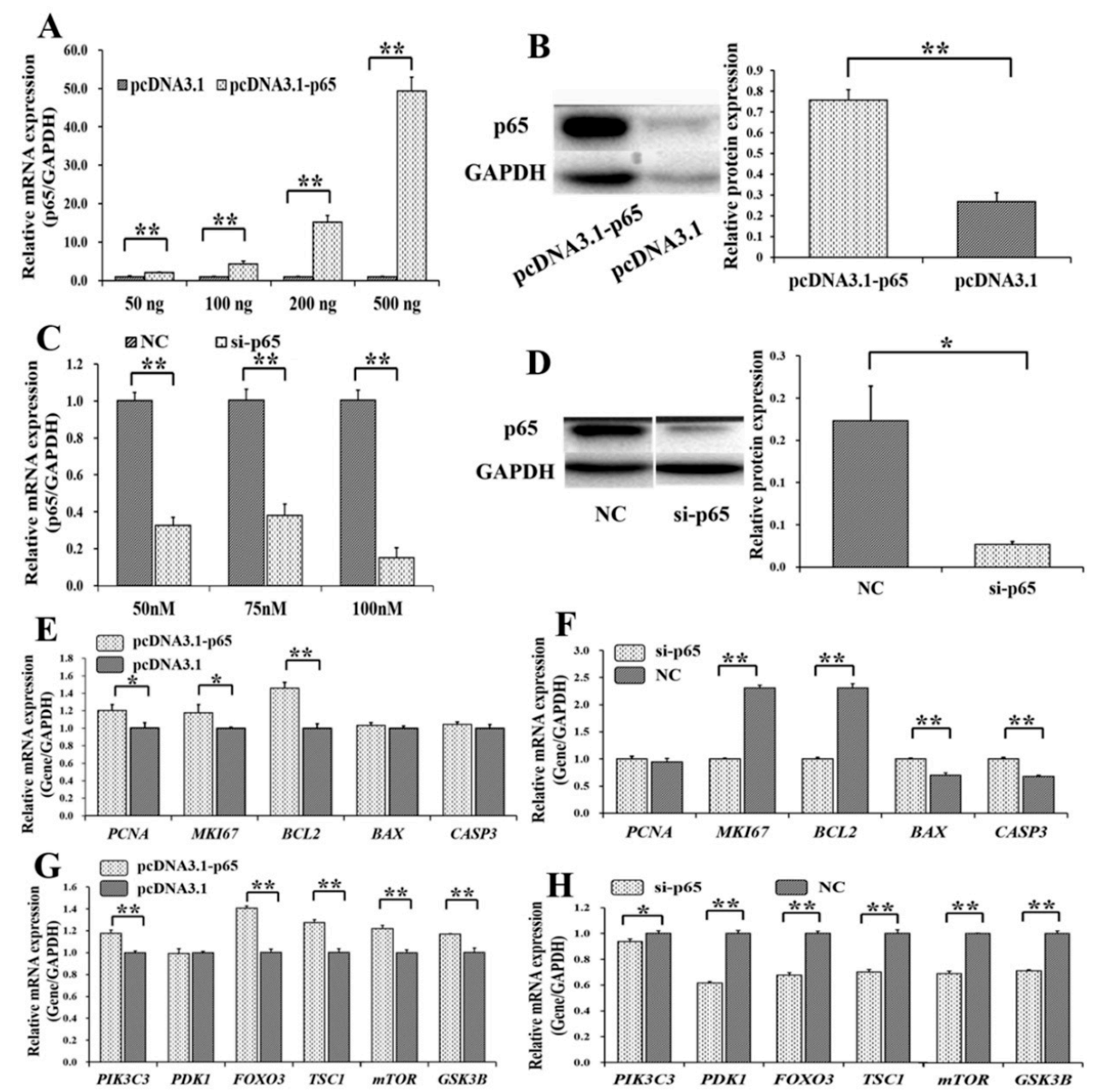

Figure 2. Biological effects of $p 65$ on apoptosis and PI3K signaling pathway. (A) The mRNA level of $p 65$ under different concentrations of pcDNA3.1-p65 plasmid; (B) the protein count of p65 was stimulated by $200 \mathrm{ng}$ of pcDNA3.1-p65 plasmid; (C) the mRNA level of $p 65$ with different concentrations of siRNAs; (D) the protein count of $p 65$ was suppressed by $70 \mathrm{nM}$ of si-p65. The relative mRNA expressions of genes from apoptosis signaling pathway after treatment by pcDNA3.1-p65 (E) and si-p65 (F); the relative mRNA expressions of genes from PI3K signaling pathway after treatment by pcDNA3.1-p65 (G) and si-p65 (H). ${ }^{*}$ indicates $p<0.05 ;{ }^{* *}$ indicates $p<0.01$. Data are represented as means \pm SD. NC: negative control. Si-p65: specific siRNA for $p 65$. PcDNA3.1-p65: pcDNA3.1 overexpression plasmid of $p 65$.

Among the genes from the apoptosis signaling pathway, pcDNA3.1-p65 was observed to significantly increase the mRNA levels of PCNA $(p<0.05)$, MKI67 $(p<0.05)$, and BCL2 $(p<0.01)$ (Figure 2E), and si-p65 significantly suppressed the mRNA levels of MKI67 $(p<0.01)$ and BCL2 
$(p<0.01)$ but upregulated the mRNA levels of BAX $(p<0.01)$ and CASP3 $(p<0.01)$ (Figure 2F). Among the genes of the PI3K signaling pathway, pcDNA3.1-p65 significantly increased the mRNA levels of PIK3C3 $(p<0.01)$, FOXO3 $(p<0.01)$, TSC1 $(p<0.01)$, mTOR $(p<0.01)$, and GSK3B $(p<0.01)$ (Figure 2G). However, si-p65 significantly decreased the mRNA levels of PIK3C3 $(p<0.05)$, PDK1 $(p<0.01)$, FOXO3 $(p<0.01)$, TSC1 $(p<0.01)$, mTOR $(p<0.01)$, and GSK3B $(p<0.01)$ (Figure $2 \mathrm{H})$.

Moreover, pcDNA3.1-65 was found to significantly increase the cell proliferation rate of GCs $(p<0.05)$ (Figure 3A), and si-65 significantly decreased the cell proliferation rate of GCs $(p<0.01)$ (Figure 3B). In addition, pcDNA3.1-p65 was observed to significantly depress the cell apoptosis rate of GCs $(p<0.01)$ (Figure 3 C), and si-p65 significantly promoted cell apoptosis in GCs $(p<0.01)$ (Figure 3D).
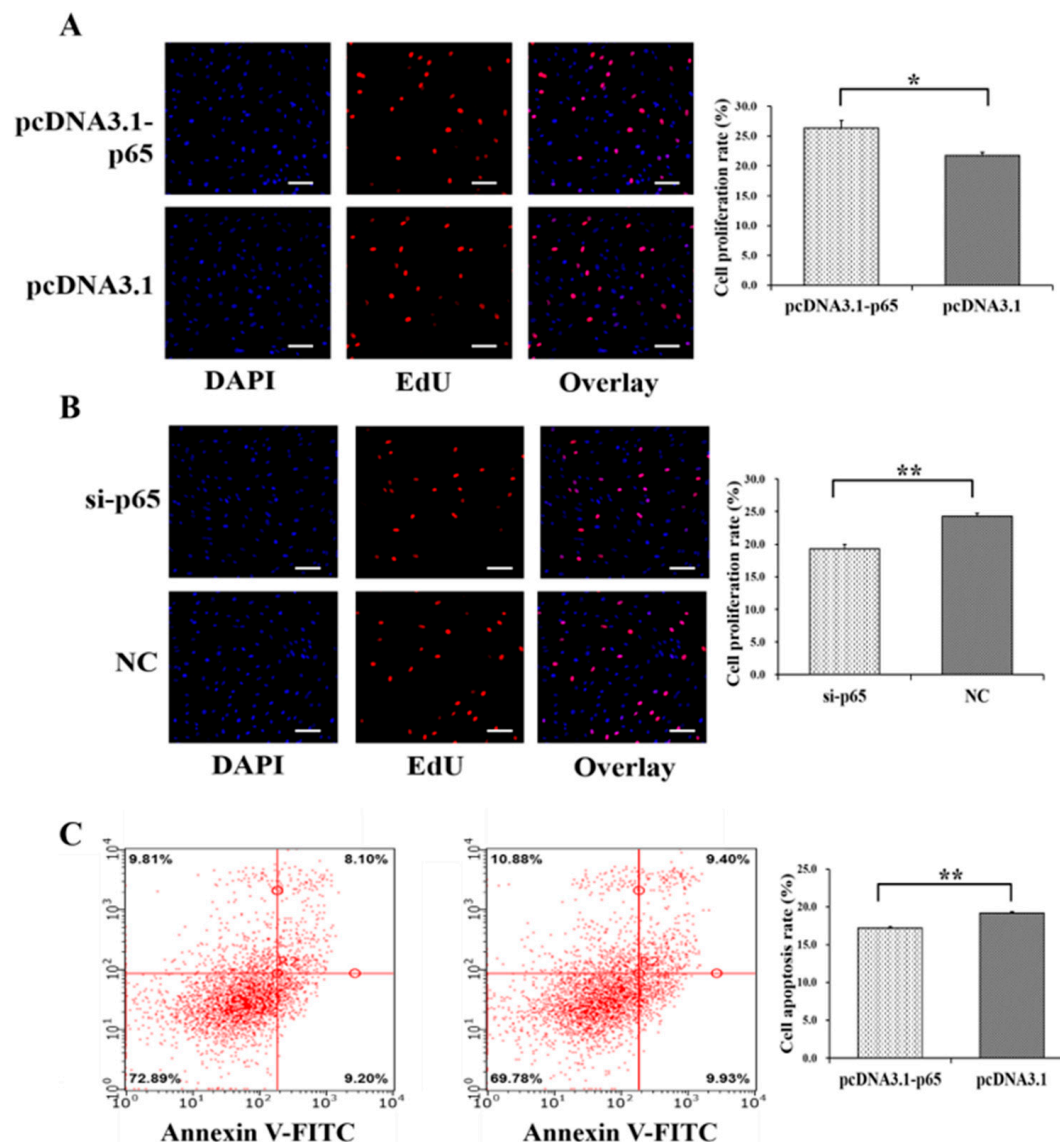

D
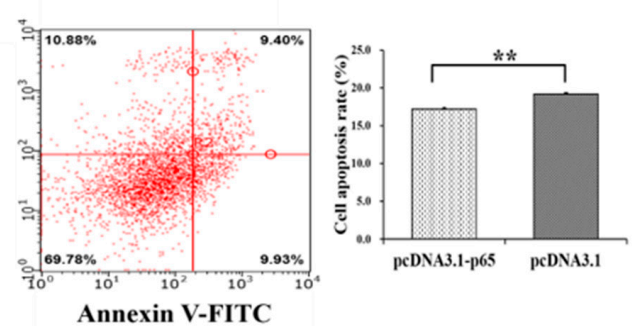

pcDNA3.1-p65 pcDNA3.1

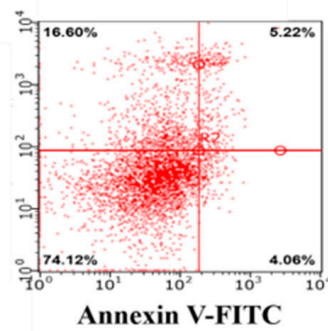

si-p65

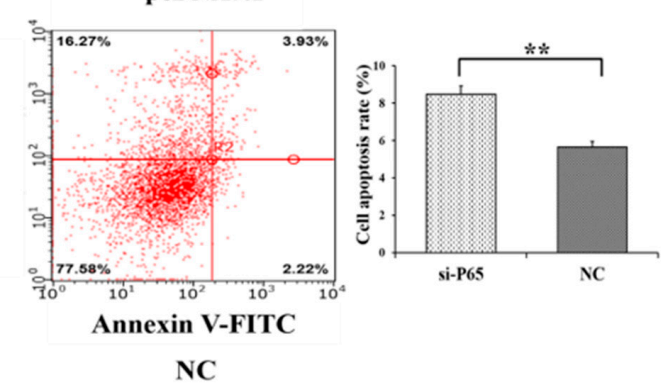

Figure 3. Biological effects of $p 65$ on cell proliferation and apoptosis of GCs. The cell proliferation rate of GCs after treatment by pcDNA3.1-p65 (A) and si-p65 (B). The cell apoptosis rate of GCs after treatment by pcDNA3.1-p65 (C) and si-p65 (D). * indicates $p<0.05$; ${ }^{* *}$ indicates $p<0.01$. Data are represented as means \pm SD. The scale bar represents $100 \mu \mathrm{m}$. NC: negative control. PcDNA3.1-p65: pcDNA3.1 overexpression plasmid of $p 65$; si-p65: specific siRNA for $p 65$. 


\section{3. p65 Targets FGFR1 and Promotes the Expression of FGFR1}

Several putative binding sites of $\mathrm{p} 65$ on the promoter of FGFR1 in pigs, mice and humans were predicted (Figure 4A). The potential binding sites of p65 were $-1673 /-1663,-1283 /-1273,-1056 /-1046$, $-746 /-736,-534 /-524$, and $-348 /-338$ on the promoter of FGFR1 in pigs (Figure $4 \mathrm{~A}$ ). To further explore the molecular mechanism for p65 regulating the expression of $F G F R 1,5^{\prime}$ deletion and gene reporter assay were constructed for FGFR1 in pigs. The $5^{\prime}$ deletion fragments of P1 (-2044/+401), P2 $(-1652 /+401)$, P3 (-1069/+401), P4 (-815/+401), P5 (-700/+401), P6 (-377/+401), and P7 (-84/+401) were amplified and cloned into the eukaryotic expression vector pGL3-Basic (Figure 4B). Compared to P1, the relative luciferase activities of P2, P3, P4, and P5 did not show significant changes (Figure 4C) with deletion of $-1673 /-1663,-1283 /-1273,-1056 /-1046$, and $-746 /-736$, respectively. After deletion of $-534 /-524$ (P5), the relative luciferase activity of P6 was significantly increased. However, after deletion of $-348 /-338$ (P6), the relative luciferase activity was significantly decreased (P7). The $-348 /-338$ region of FGFR1 is surrounded by the GC and TATA box. Moreover, the expression patterns of p65 and FGFR1 were positively correlated in small and large follicles (Figure 1E-H), indicating that P6 might harbor the exact binding site of $\mathrm{p} 65$.
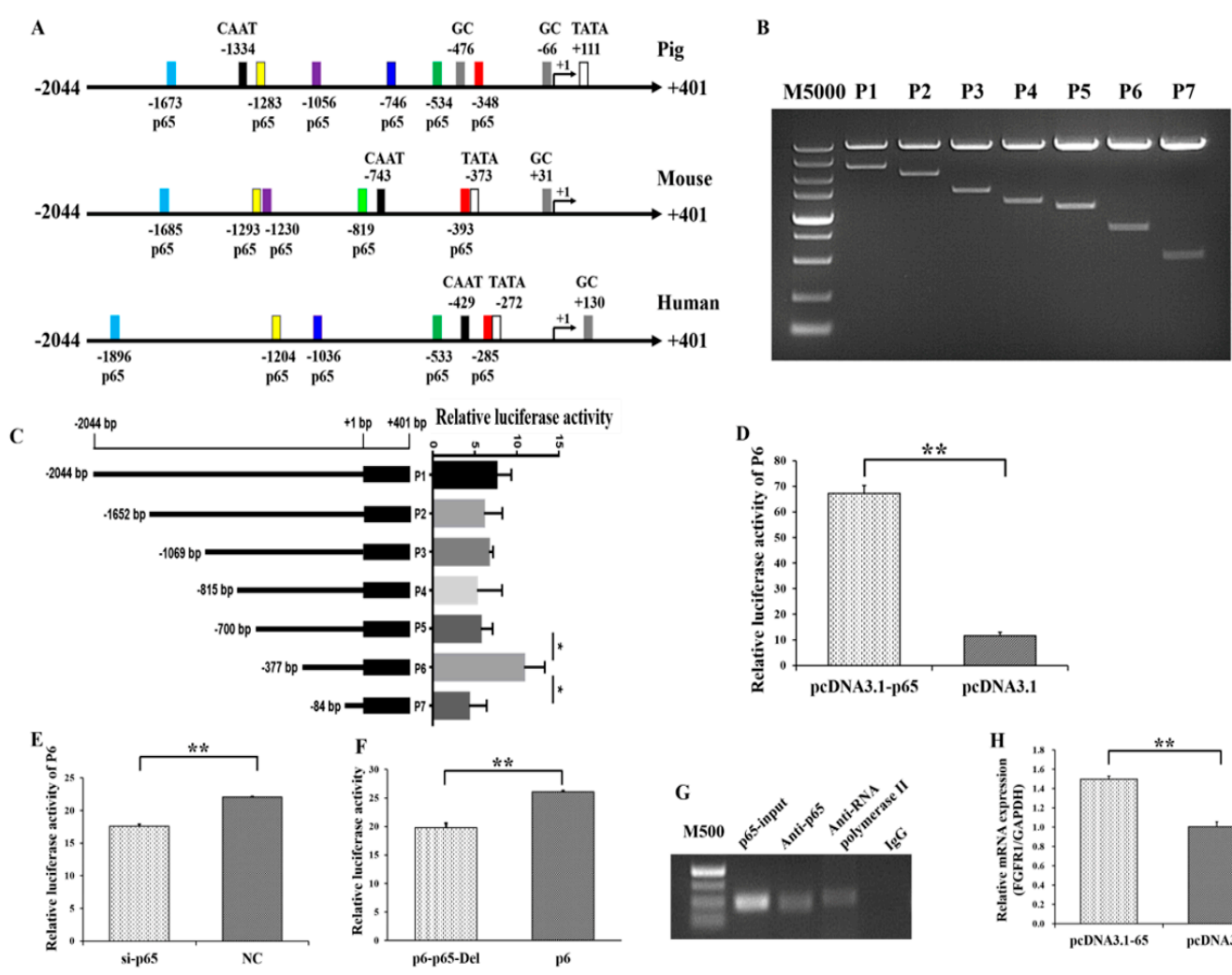

$+1 \mathrm{bp}+401$ bp Relative luciferase activity
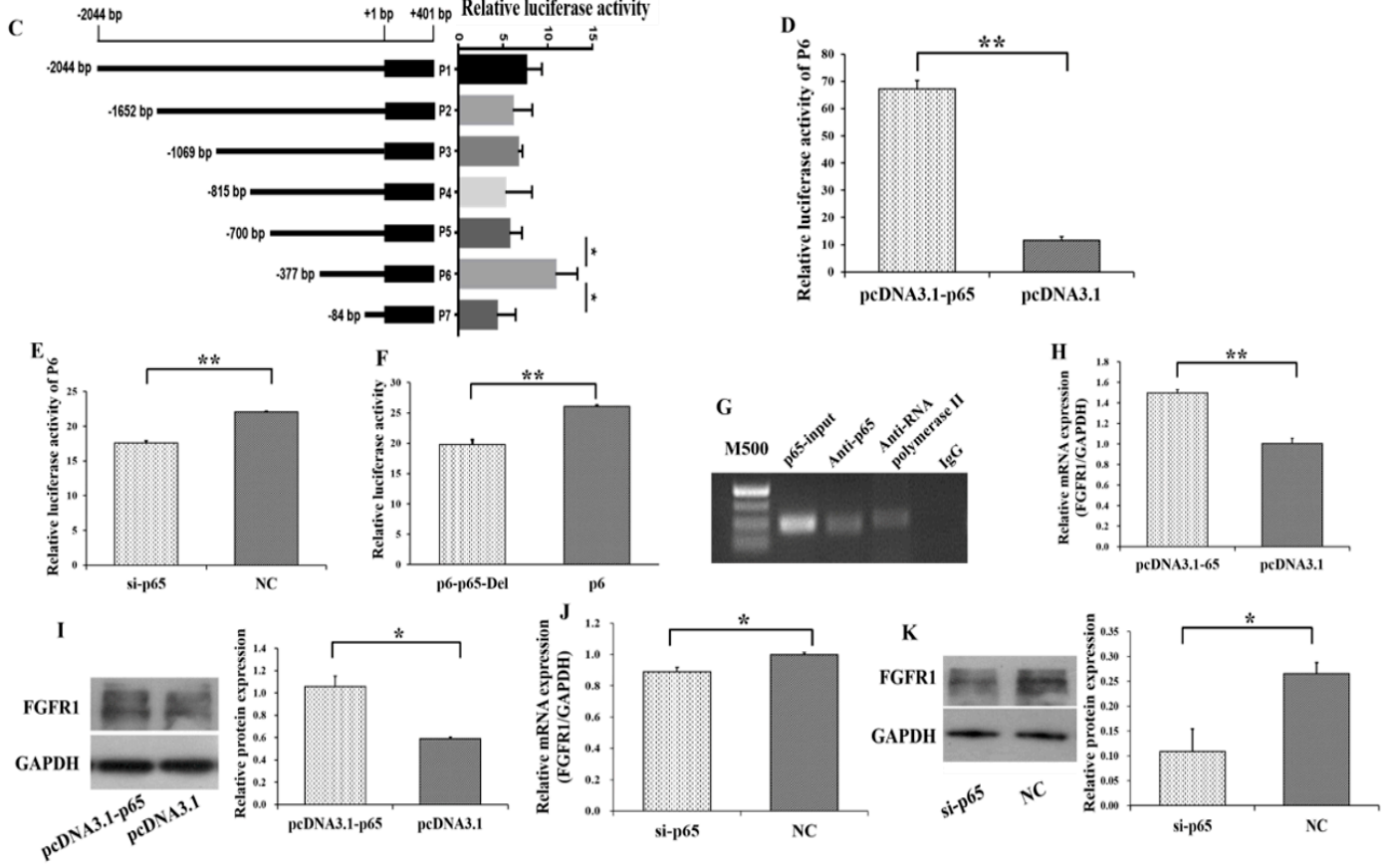
Figure 4. p65 binds to the $-348 /-338$ region of FGFR1 and positively regulate the expression of FGFR1. (A) The putative binding sites of p65 on the promoter of FGFR1; (B) PCR products of 5' deletion fragments from promoter of FGFR1; (C) the relative luciferase activity of FGFR1 promoter after $5^{\prime}$ deletion of the putative binding sites of p65; (D) the relative luciferase activity of P6 with overexpression of p65; (E) the relative luciferase activity of P6 with interfering with expression of p65; (F) the relative luciferase activity of P6 after specific deletion of -348/-338; (G) confirmation of p65 binding at $-348 /-338$ by chromatin immunoprecipitation (ChIP) assay. The relative mRNA (H) and protein (I) levels of FGFR1 stimulated by pcDNA3.1-p65; the relative mRNA (J) and protein (K) levels of FGFR1 inhibited by si-p65. * indicates $p<0.05$; ${ }^{* *}$ indicates $p<0.01$. Data are represented as means \pm SD. CAAT: CAAT box; TATA: TATA box: GC: GC box; M5000: DNA markers of 5000 bp. M500: DNA markers of 500 bp. Si-p65: specific siRNA for p65; NC: negative control. pcDNA3.1-p65: pcDNA3.1 overexpression plasmid of $p 65$.

Furthermore, the relative luciferase activity of P6 was significantly increased by pcDNA3.1-p65 (Figure 4D) and was significantly decreased by si-65 (Figure 4E). To further validate FGFR1 as a target of $\mathrm{p} 65$, the $-348 /-338$ region of P6 was further specifically deleted, and this deletion significantly decreased the relative luciferase activity (Figure $4 \mathrm{~F}$ ). The results of the chromatin immunoprecipitation (ChIP) assay on P6 further confirmed that p65 binds at the -348/-338 region of FGFR1 (Figure 4G). To identify whether $\mathrm{p} 65$ regulates the expression of FGFR1, the expression of FGFR1 was determined after transfection with pcDNA3.1-p65 or si-p65 into GCs. The mRNA $(p<0.01$, Figure $4 \mathrm{H})$ and protein $(p<0.05$, Figure 4I) levels of FGFR1 were significantly increased by pcDNA3.1-65, and the mRNA $(p<0.05$, Figure 4J) and protein $(p<0.05$, Figure 4K) levels of FGFR1 could be significantly decreased by si-65. These results indicated that p65 might upregulate the transcription and expression of FGFR1 in GCs.

\subsection{Pro-Proliferation and Anti-Apoptotic Effects of FGFR1 on GCs}

To determine the biological effects of FGFR1 on the PI3K and apoptosis signaling pathways, as well as cell survival, overexpression plasmids and specific siRNAs of FGFR1 were built and created (Figure 5). In GCs, the mRNA level of FGFR1 was increased along with the concentration of pcDNA3.1-FGFR1 (Figure 5A). We selected $200 \mathrm{ng}$ of pcDNA3.1-FGFR1 plasmid for further use, and $200 \mathrm{ng}$ of pcDNA3.1-FGFR1 was observed to significantly increase the protein level of FGFR1, compared to pcDNA3.1-basic (Figure 5B). Quantities of $50 \mathrm{nM}, 75 \mathrm{nM}$, and $100 \mathrm{nM}$ of siRNA specific for FGFR1 (si-FGFR1) were found to significantly decrease the mRNA level of FGFR1 (Figure 5C), and $75 \mathrm{nM}$ of si-FGFR1 was selected for further use based on considerations of cellular tolerance. We found that $75 \mathrm{nM}$ of si-FGFR1 significantly decreased the level of FGFR1 protein, compared to the NC group (Figure 5D).

Among the genes of the apoptosis signaling pathway, pcDNA3.1-FGFR1 was found to significantly increase the mRNA levels of MKI67 $(p<0.05)$ and BCL2 $(p<0.01)$ but significantly decrease the mRNA levels of $B A X(p<0.05)$ (Figure 5E), and si-p65 significantly decreased the mRNA levels of MKI67 ( $p<0.01$ ) (Figure 5F). Among the genes of the PI3K signaling pathway, pcDNA3.1-FGFR1 was observed to significantly decrease the mRNA levels of PDK1 $(p<0.05)$ and GSK3B $(p<0.05)$ (Figure 5G), and si-FGFR1 was observed to significantly increase the mRNA levels of PIK3C3 $(p<0.01), P D K 1$ $(p<0.01)$, and GSK3B $(p<0.05)$ but significantly decrease the mRNA levels of FOXO3 $(p<0.01)$, TSC1 $(p<0.01)$, and mTOR $(p<0.05)$ (Figure 5H). Moreover, pcDNA3.1-FGFR1 significantly increased the cell proliferation rate (Figure 6A), and si-FGFR1 significantly decreased the cell proliferation rate in GCs (Figure 6B). pcDNA3.1-FGFR1 significantly depressed the cell apoptosis rate (Figure 6C), and si-FGFR1 significantly increased the cell apoptosis rate (Figure 6D) in GCs. 
A

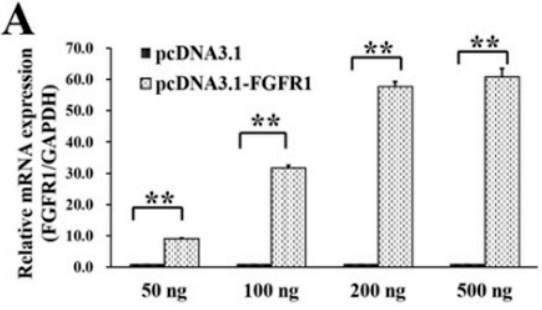

C
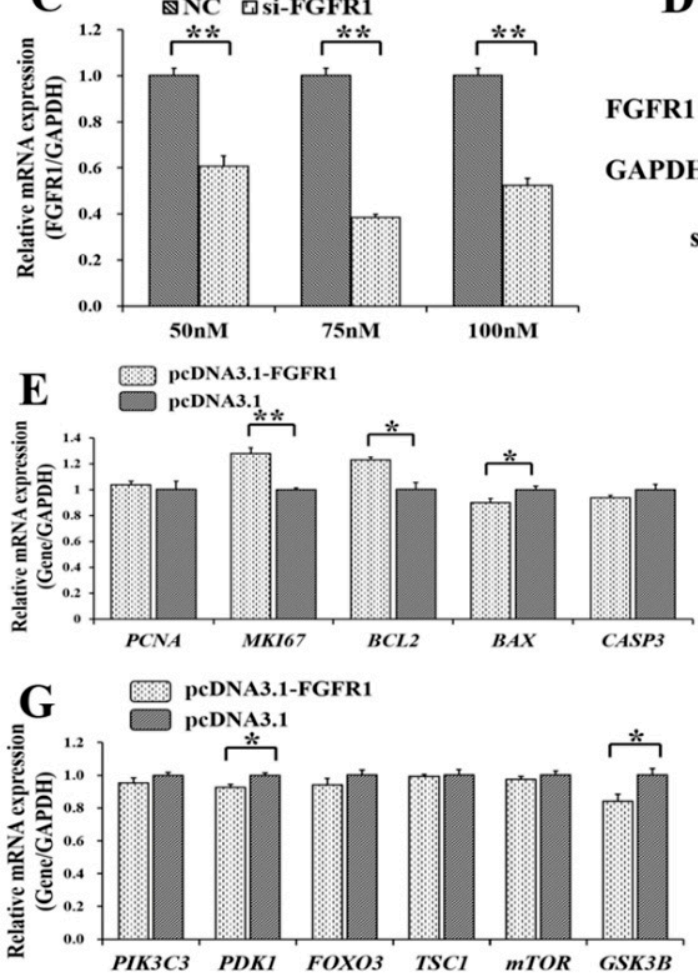

D
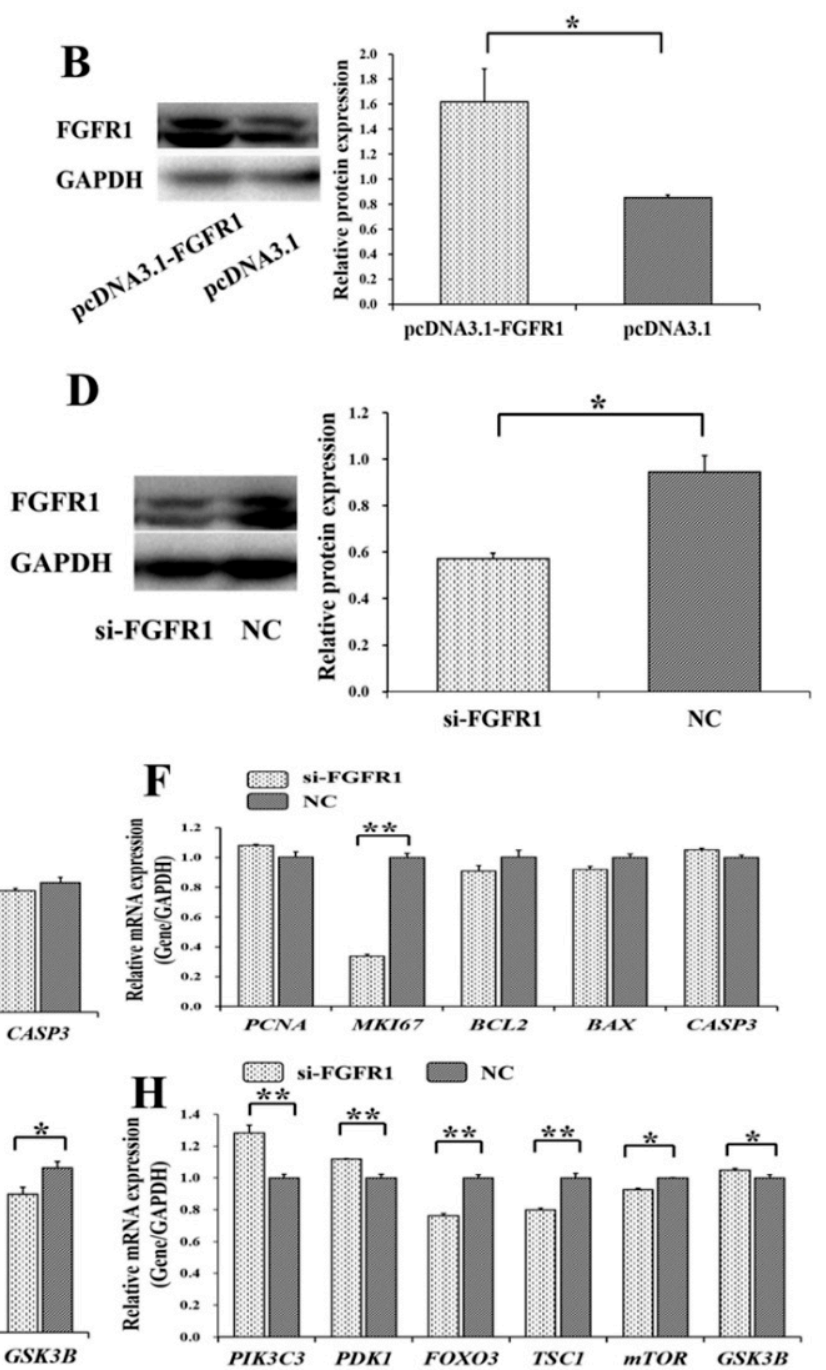

Figure 5. Biological effects of FGFR1 on apoptosis and PI3K signaling pathway. (A) The mRNA level of FGFR1 under different concentrations of pcDNA3.1-FGFR1 plasmid; (B) the FGFR1 protein count was stimulated by $200 \mathrm{ng}$ of pcDNA3.1-FGFR1 plasmid; (C) the mRNA level of FGFR1 with different concentrations of siRNAs; (D) the FGFR1 protein count was suppressed by $70 \mathrm{nM}$ of si-FGFR1. The relative mRNA expressions of genes from apoptosis signaling pathway after treatment by pcDNA3.1-FGFR1 (E) and si-FGFR1 (F); The relative mRNA expressions of genes from PI3K signaling pathway after treatment by pcDNA3.1-FGFR1 (G) and si-FGFR1 (H). ${ }^{*}$ indicates $p<0.05$; ${ }^{* *}$ indicates $p<0.01$. Data are represented as means \pm SD. NC: negative control. Si-FGFR1: specific siRNA for FGFR1. PcDNA3.1-FGFR1: pcDNA3.1 overexpression plasmid of FGFR1. 


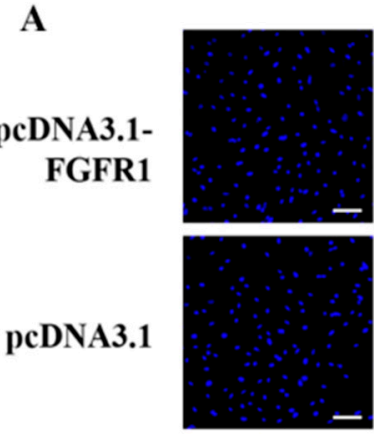

DAPI

B

si-FGFR1

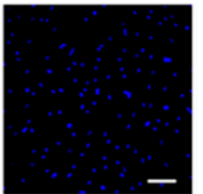

NC

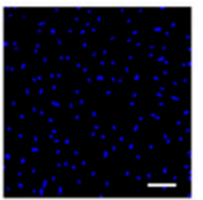

DAPI

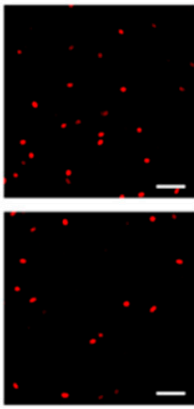

EdU
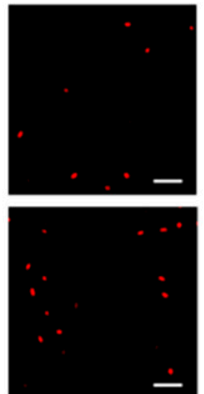

EdU

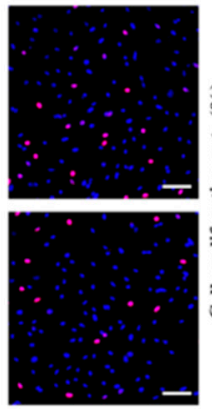

Overlay
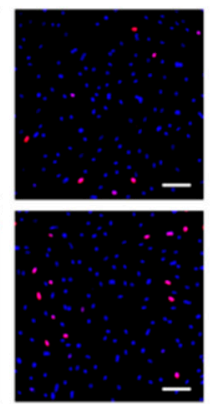

Overlay
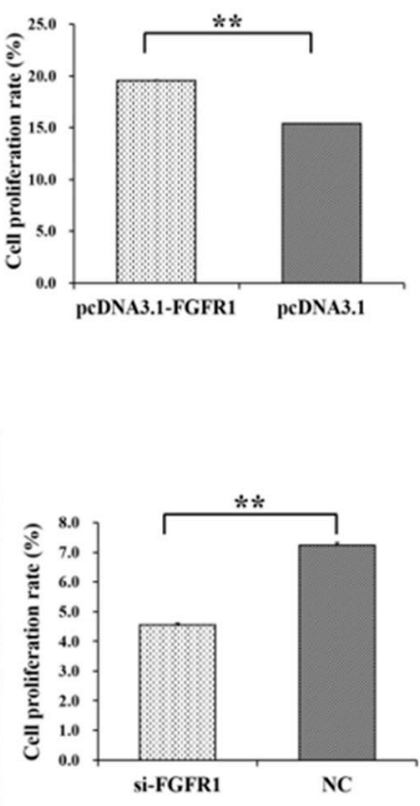

C

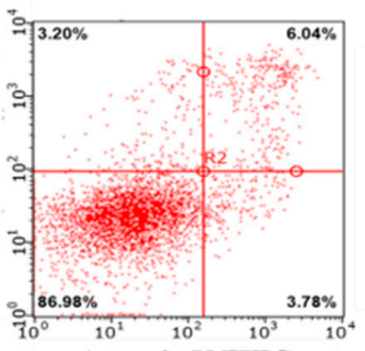

D
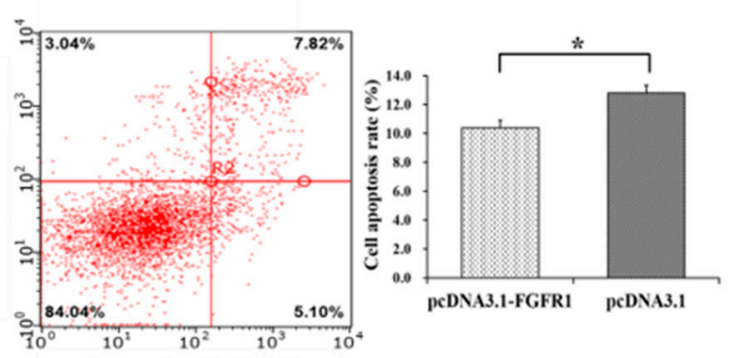

Annexin V-FITC

peDNA3.1
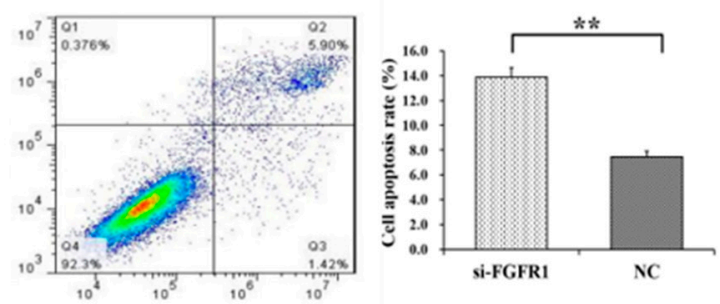

Annexin V-FITC

NC

Figure 6. Biological effects of FGFR1 on cell proliferation and apoptosis of GCs. The cell proliferation rate of GCs after treatment by pcDNA3.1-FGFR1 (A) and si-FGFR1 (B). The cell apoptosis rate of GCs after treatment by pcDNA3.1-FGFR1 (C) and si-FGFR1 (D). ${ }^{*}$ indicates $p<0.05$; ${ }^{* *}$ indicates $p<0.01$. Data are represented as means \pm SD. The scale bar represents $100 \mu \mathrm{m}$. NC: negative control; PcDNA3.1-FGFR1: pcDNA3.1 overexpression plasmid of FGFR1; Si-FGFR1: specific siRNA for FGFR1.

\section{5. p65 Enhances the Pro-Proliferation and Anti-Apoptotic Effects of FGFR1 in GCS}

To further investigate the biological effects of $p 65$ on the functions of FGFR1, pcDNA3.1-FGFR1, pcDNA3.1-p65, si-FGFR1 and si-p65 were co-transfected into GCs. For cell proliferation, pcDNA3.1-FGFR1 + pcDNA3.1-p65 was found to be markedly higher than pcDNA3.1-FGFR1 + pcDNA3.1 (Figure 7A), and si-FGFR1 + si-p65 was significantly lower than si-FGFR1 + NC (Figure 7B). These results indicated that 
p65 might enhance the pro-proliferation effect of FGFR1 in GCs. For cell apoptosis, pcDNA3.1-FGFR1 + pcDNA3.1-p65 was found to be significantly lower than pcDNA3.1-FGFR1 + pcDNA3.1 (Figure 7C), and si-FGFR1 + si-p65 was significantly higher than si-FGFR1 + NC (Figure 7D). These results implied that $p 65$ might enhance the anti-apoptotic effect of FGFR1 in GCs.

A
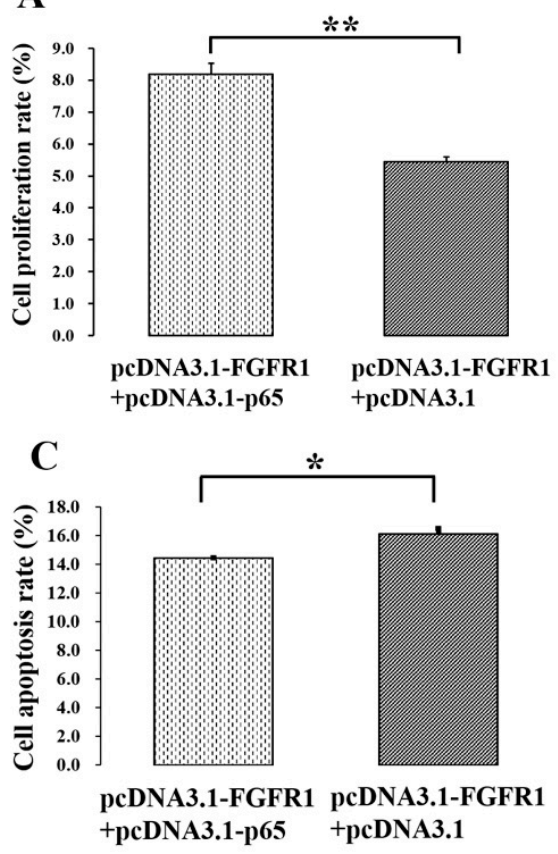

B
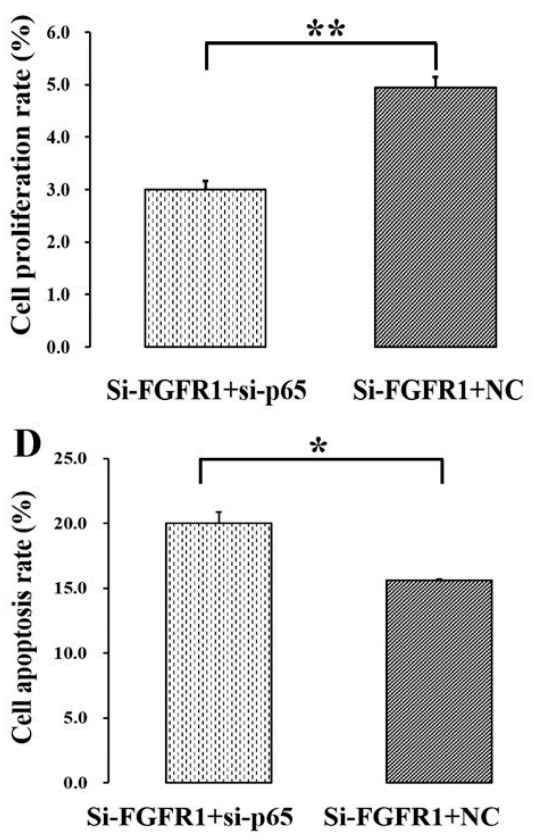

Figure 7. $p 65$ enhances the pro-proliferation and anti-apoptotic effects of FGFR1 in GCs. (A) PcDNA3.1-p65 increased the cell proliferation rate of pcDNA3.1-FGFR1 in GCs; (B) si-p65 decreased the cell proliferation rate of si-FGFR1 in GCs; (C) pcDNA3.1-p65 depressed the cell apoptosis rate of pcDNA3.1-FGFR1 in GCs; (D) si-p65 stimulated the cell apoptosis rate of si-FGFR1 in GCs. Data are represented as means \pm SD. NC: negative control; PcDNA3.1-FGFR1: pcDNA3.1 overexpression plasmid of FGFR1; PcDNA3.1-p65: pcDNA3.1 overexpression plasmid of p65; si-FGFR1: specific siRNA for FGFR1; si-p65: specific siRNA for $p 65$; NC: negative control; * indicates $p<0.05 ;{ }^{* *}$ indicates $p<0.01$.

\section{Discussion}

In mammals, previous studies have suggested that the survival of GCs decides the fate of follicles [4,5]. It is well known that the positive proliferation of GCs facilitates the development of follicles, but that the excessive apoptosis of GCs impairs the growth of follicles, induces the atresia of follicles $[4,5,26]$, and even results in delayed sexual maturation [27]. The transcription factor p65, one core subunit of NF- $\mathrm{kB}$, regulates the proliferation and apoptosis of many ovarian cells $[18,28]$. The FGFR1 gene is the critically important regulator of the proliferation of GCs [9] and follicular development [11,12]. In this study, we found that p65 targeted at the $-348 /-338$ region of FGFR1, promoted the transcription of FGFR1, and enhanced the pro-proliferation and anti-apoptotic effect of FGFR1 to facilitate the growth of follicles. This study will provide useful information for further investigations on the p65-mediated-FGFR1 signal pathway during folliculogenesis in mammals. Generally, once p65 has formed heterodimers with one of the other NF-kB proteins, e.g., p50, the NF- $k B$ signaling pathway is activated. Then released NF- $k B$ will transmigrate from translocation into the nucleus and bind to DNA to regulate the expression of target genes [29]. However, many studies have suggested that p65 is different from p50 in regulating the transcription of targeted genes $[18,30]$. For example, it is the p65/p65 or p50/p50 homodimer, not the p65/p50 heterodimer, that directly regulates the expression of target genes to mediate cell survival in humans [30,31], and the homodimer of p50/50 or p65/p65 controls basic ovarian functions in pigs [17]. These observations support the idea 
that the p65/p65 homodimer may control the expression of FGFR1 to regulate the survival of GCs in pigs.

In this study, the mRNA and protein levels of FGFR1 were significantly increased by p65 (Figure 4H-K), and the expression pattern of FGFR1 was in line with that of $\mathrm{p} 65$ in small and large follicles (Figure 1E-H). These results indicated that p65 might upregulate the expression of FGFR1 in porcine GCs. To further investigate whether $\mathrm{p} 65$ regulates the transcription of FGFR1, several 5' deletion fragments of the promoter of FGFR1 and the luciferase report assay were created (Figure 4B,C). After deletion of the $-348 /-338$ region of $\mathrm{P} 6$, the relative luciferase activity of $\mathrm{P} 7$ was significantly decreased (Figure 4C), and p65 significantly increased the relative luciferase activity of P6 (Figure 4D,E). After specific deletion of the $-348 /-338$ region of P6, the relative luciferase activity of P6 significantly decreased (Figure 4F). Moreover, the results of the ChIP assay on P6 confirmed that p65 binds at the $-348 /-338$ region of FGFR1 (Figure 4G), and p65 was observed to enhance the pro-proliferation effect and anti-apoptotic effect of FGFR1 (Figure 7). These results demonstrated that p65 targeted the $-348 /-338$ region of FGFR1 to positively regulate the expression of FGFR1 in porcine GCs. Additionally, there were also several potential binding sties on the promoter of FGFR1 in humans, pigs, and mice (Figure $4 \mathrm{~A}$ ), and the locations of these potential binding sties were likely to converge among humans, mice, and pigs (Figure 4A). Moreover, the confirmed binding site of p65 (-348/-338 region) on the promoter of FGFR1 in pigs was the nearest one to the transcription start site and was surrounded by the TATA box and GC box (Figure 4A). The nearest putative binding site of p65 to the transcription start site being surrounded by the TATA box and GC box was also observed in humans or mice (Figure 4A). These observations indicated that p65 might regulate the expression of FGFR1 in mammals.

To explore the biological functions of $p 65$ and FGFR1 on cell survival of GCs, the expressions of genes from the apoptosis signaling pathway were detected after knockdown or overexpression of $p 65$ (Figure 2) and FGFR1 (Figure 5) in GCs. Among the apoptosis-related genes, the mRNA levels of the proliferation markers PCNA and MKI67 and the anti-apoptotic gene BCL2 were significantly increased by overexpression of $p 65$ (Figure $2 \mathrm{E}$ ), and the mRNA levels of MKI67 and BCL2 were significantly decreased by interfering with the expression of $p 65$ (Figure 2F). Furthermore, the mRNA levels of MKI67 and BCL2 were also significantly upregulated by overexpression of FGFR1 (Figure 5E), and the mRNA level of MKI67 was significantly downregulated by interfering with the expression of FGFR1 (Figure 5F). Previous studies have suggested that MK167 presents exclusively in proliferating cells and servers as a marker for proliferation [32]. In mouse GCs, the expression patterns of MKI67 were coupled with the patterns of follicle-stimulating hormone receptor [33]. Compared to wild-type mice, the expression of MKI67 in GCs is significantly lower than in GC-specific steroidogenic factor 1 deficiency mice with impaired follicle development and infertility [34]. BCL2, known to be an apoptosis regulator, has been reported to block the apoptotic death [35] of GCs in bovines [36] and humans [37].

Additionally, the mRNA levels of apoptotic activators such as BAX and CASP3 were significantly upregulated by interfering with the expression of p65 (Figure 2F), and the mRNA levels of $B A X$ and CASP3 were upregulated by interfering with expression of FGFR1 (Figure 5F), although the change in the expression of $C A S P 3$ was not statistically significant (Figure $5 F$ ). It is well known that $B A X$ functions as an apoptotic activator and apoptosis marker. The induced expression of $B A X$ is likely to trigger cell apoptosis in GCs of mice [38,39]. Higher expressions of CASP3, one of the pro-apoptotic genes, induce the apoptosis of GCs in bovines [36]. Downregulation of the pro-apoptotic CASP3 gene inhibits the apoptosis of GCs in pigs [40]. The mRNA level of CASP3 in GCs is negatively associated with the number of preovulatory follicles in humans, indicating that the accumulation of CASP3 impairs the development of follicles [41]. Furthermore, the cell proliferation rate was significantly promoted by p65 (Figure 3A,B) or FGFR1 (Figure 6A,B), and the cell apoptosis rate was significantly suppressed by p65 (Figure 3C,D) or FGFR1 (Figure 6C,D). These observations suggested that both $p 65$ and FGFR1 might promote cell proliferation and inhibit cell apoptosis in porcine GCs. 
Previous studies have indicated that the PI3K signaling pathway plays an important role in regulation of cell survival of GCs [42,43]. Because of the FGFR1 gene from the PI3K signaling pathway, the mRNA levels of some other genes from the PI3K signaling pathway were also detected after knockdown or overexpression of $p 65$ (Figure 2G,H) and FGFR1 (Figure 5G,H) in GCs. We found that the mRNA levels of $P D K 1$ and GSK2B were significantly downregulated by overexpression of FGFR1 (Figure 5G), and the mRNA levels of PIK3C3, PDK1, GSK3B were significantly upregulated but that of FOXO3, TSC1 and $m T O R$ were significantly downregulated by interference with the expression of FGFR1 (Figure 5H). Furthermore, the mRNA levels of PIK3C3, FOXO3, TSC1, mTOR, and GSK3B were significantly increased by overexpression of $p 65$ (Figure 2G) but were significantly decreased by interfering with the expression of $p 65$ (Figure 2H). The mRNA level of PDK1 was also significantly decreased by interfering with the expression of $p 65$ (Figure 2H). A previous study has suggested that a high expression level of PIK3C is associated with follicular development and subfertility in mice [44]. A high mRNA level of PDK1 depresses cell apoptosis and affects cell entry in porcine GCs [45]. FOXO3-specific-depletion in GCs decreases both cell proliferation and apoptosis of GCs and disrupts follicular growth in mice [46], and a lower mRNA expression of FOXO3 in GCs is involved in infertility in women [47]. TSC1-specific-knockout in GCs stimulates the development of follicles in mice [48], and moreover, interfering with the expression of TSC1 significantly promotes cell proliferation and inhibits cell apoptosis in porcine GCs [23]. The mTOR gene has been reported to mediate cellular responses to stress such as DNA damage and to determine the fate of GCs in mice [49]. Inhibition of the expression of GSK3B represses the growth of GCs in humans [50]. These results suggest that both p65 and FGFR1 might regulate the biological functions of GCs during follicular development via the PI3K signaling pathway.

Author Contributions: Conceptualization, X.Y., Z.L., and J.L.; methodology, Z.L., Y.K., Y.Z., and A.Z.; validation, Z.L., Y.Z., Y.K. and A.Z.; formal analysis, X.Y. and Y.J.; investigation, Z.L. and Y.J.; resources, Y.H. and X.Z.; writing-original draft preparation, X.Y. and Z.L.; writing — review and editing, Z.Z., H.Z. and J.L.; visualization, X.Y.; supervision, J.L.; funding acquisition, X.Y., J.L., and A.Z.

Funding: This work was supported by the National Natural Science Foundation of China (31902131), the Natural Science Foundation of Guangdong Province (2019A1515010676), the Youth Innovative fund of Guangdong Education Department (2018KQNCX019), the earmarked fund for China Agriculture Research System (CARS-35) and Guangdong Sailing Program (2014YT02H042) and the Science and Technology Program of Guangzhou (201707010001).

Data Availability Statements: The datasets used in the current study are available from the corresponding author on reasonable request.

Conflicts of Interest: The authors declare no conflict of interest.

\section{References}

1. Hunter, M.G. Oocyte maturation and ovum quality in pigs. Rev. Reprod. 2000, 5, 122-130. [CrossRef] [PubMed]

2. McGee, E.A.; Hsueh, A.J. Initial and cyclic recruitment of ovarian follicles. Endocr. Rev. 2000, 21, $200-214$. [CrossRef] [PubMed]

3. Soede, N.M.; Langendijk, P.; Kemp, B. Reproductive cycles in pigs. Anim. Reprod. Sci. 2011, 124, $251-258$. [CrossRef] [PubMed]

4. Matsuda, F.; Inoue, N.; Manabe, N.; Ohkura, S. Follicular growth and atresia in mammalian ovaries: Regulation by survival and death of granulosa cells. J. Reprod. Dev. 2012, 58, 44-50. [CrossRef]

5. Manabe, N.; Goto, Y.; Matsuda-Minehata, F.; Inoue, N.; Maeda, A.; Sakamaki, K.; Miyano, T. Regulation mechanism of selective atresia in porcine follicles: Regulation of granulosa cell apoptosis during atresia. J. Reprod. Dev. 2004, 50, 493-514. [CrossRef]

6. Shao, Y.Y.; Chang, Z.P.; Cheng, Y.; Wang, X.C.; Zhang, J.P.; Feng, X.J.; Guo, Y.T.; Liu, J.J.; Hou, R.G. Shaoyao-Gancao Decoction alleviated hyperandrogenism in a letrozole-induced rat model of polycystic ovary syndrome by inhibition of NF-kappaB activation. Biosci. Rep. 2019, 39. [CrossRef] 
7. Owens, L.A.; Kristensen, S.G.; Lerner, A.; Christopoulos, G.; Lavery, S.; Hanyaloglu, A.C.; Hardy, K.; Yding Andersen, C.; Franks, S. Gene expression in granulosa cells from small antral follicles from women with or without polycystic ovaries. J. Clin. Endocrinol. Metab. 2019. [CrossRef]

8. Pfieffer, M.L. Polycystic ovary syndrome: An update. Nursing 2019, 49, 34-40. [CrossRef]

9. Mishra, S.R.; Thakur, N.; Somal, A.; Parmar, M.S.; Reshma, R.; Rajesh, G.; Yadav, V.P.; Bharti, M.K.; Bharati, J.; Paul, A.; et al. Expression and localization of fibroblast growth factor (FGF) family in buffalo ovarian follicle during different stages of development and modulatory role of FGF2 on steroidogenesis and survival of cultured buffalo granulosa cells. Res. Vet. Sci. 2016, 108, 98-111. [CrossRef]

10. Berisha, B.; Schams, D.; Kosmann, M.; Amselgruber, W.; Einspanier, R. Expression and localisation of vascular endothelial growth factor and basic fibroblast growth factor during the final growth of bovine ovarian follicles. J. Endocrinol. 2000, 167, 371-382. [CrossRef]

11. Lin, X.; Ma, Y.; Qian, T.; Yao, J.; Mi, Y.; Zhang, C. Basic fibroblast growth factor promotes prehierarchical follicle growth and yolk deposition in the chicken. Theriogenology 2019, 139, 90-97. [CrossRef] [PubMed]

12. Guo, C.; Zhang, G.; Lin, X.; Zhao, D.; Zhang, C.; Mi, Y. Reciprocal stimulating effects of bFGF and FSH on chicken primordial follicle activation through AKT and ERK pathway. Theriogenology 2019, 132, 27-35. [CrossRef] [PubMed]

13. Topaloglu, A.K. Update on the Genetics of Idiopathic Hypogonadotropic Hypogonadism. J. Clin. Res. Pediatr. Endocrinol. 2017, 9, 113-122. [CrossRef] [PubMed]

14. Howard, S.R. The Genetic Basis of Delayed Puberty. Front. Endocrinol. 2019, 10, 423. [CrossRef] [PubMed]

15. Berisha, B.; Sinowatz, F.; Schams, D. Expression and localization of fibroblast growth factor (FGF) family members during the final growth of bovine ovarian follicles. Mol. Reprod. Dev. 2004, 67, 162-171. [CrossRef]

16. Lin, J.; Jia, Y.; Zeng, W.; Mi, Y.; Zhang, C. Basic FGF promotes proliferation of ovarian granulosa cells in the laying chickens via FGFR1 and PKC pathway. Reprod. Domest. Anim. 2012, 47, 135-142. [CrossRef]

17. Pavlova, S.; Klucska, K.; Vasicek, D.; Kotwica, J.; Sirotkin, A.V. Transcription factor NF-kappaB (p50/p50, p65/p65) controls porcine ovarian cells functions. Anim. Reprod. Sci. 2011, 128, 73-84. [CrossRef]

18. Xu, J.J.; Wang, G.; Luo, X.; Wang, L.J.; Bao, Y.; Yang, X. Role of nuclear factor-kappaB pathway in the transition of mouse secondary follicles to antral follicles. J. Cell Physiol. 2019, 234, 22565-22580. [CrossRef]

19. Hou, Y.; Wang, Y.; Xu, S.; Qi, G.; Wu, X. Bioinformatics identification of microRNAs involved in polycystic ovary syndrome based on microarray data. Mol. Med. Rep. 2019, 20, 281-291. [CrossRef]

20. Peluso, J.J.; Pru, C.A.; Liu, X.; Kelp, N.C.; Pru, J.K. Progesterone receptor membrane component 1 and 2 regulate granulosa cell mitosis and survival through a NFKappaB-dependent mechanismdagger. Biol. Reprod. 2019, 100, 1571-1580. [CrossRef]

21. Gao, H.; Lin, L.; Haq, I.U.; Zeng, S.M. Inhibition of NF-kappaB promotes autophagy via JNK signaling pathway in porcine granulosa cells. Biochem. Biophys. Res. Commun. 2016, 473, 311-316. [CrossRef] [PubMed]

22. Yuan, X.; Zhou, X.; He, Y.; Zhong, Y.; Zhang, A.; Zhang, Z.; Zhang, H.; Li, J. C/EBPbeta Promotes STAT3 Expression and Affects Cell Apoptosis and Proliferation in Porcine Ovarian Granulosa Cells. Genes (Basel) 2018, 9. [CrossRef] [PubMed]

23. Yuan, X.; Deng, X.; Zhou, X.; Zhang, A.; Xing, Y.; Zhang, Z.; Zhang, H.; Li, J. MiR-126-3p promotes the cell proliferation and inhibits the cell apoptosis by targeting TSC1 in the porcine granulosa cells. In Vitro Cell Dev. Biol. Anim. 2018, 54, 715-724. [CrossRef] [PubMed]

24. Men, Y.; Fan, Y.H.; Shen, Y.Y.; Lu, L.G.; Kallen, A.N. The Steroidogenic Acute Regulatory Protein (StAR) Is Regulated by the H19/let-7 Axis. Endocrinology 2017, 158, 402-409. [CrossRef]

25. Wang, S.; Yang, S.; Lai, Z.; Ding, T.; Shen, W.; Shi, L.; Jiang, J.; Ma, L.; Tian, Y.; Du, X.; et al. Effects of culture and transplantation on follicle activation and early follicular growth in neonatal mouse ovaries. Cell Tissue Res. 2013, 354, 609-621. [CrossRef]

26. Asselin, E.; Xiao, C.W.; Wang, Y.F.; Tsang, B.K. Mammalian follicular development and atresia: Role of apoptosis. Biol. Signals Recept. 2000, 9, 87-95. [CrossRef]

27. Phoophitphong, D.; Srisuwatanasagul, S.; Koonjaenak, S.; Tummaruk, P. Apoptotic Cell Localization in Preantral and Antral Follicles in Relation to Non-cyclic and Cyclic Gilts. Reprod. Domest. Anim. 2016, 51, 400-406. [CrossRef]

28. Jiang, J.Y.; Cheung, C.K.; Wang, Y.; Tsang, B.K. Regulation of cell death and cell survival gene expression during ovarian follicular development and atresia. Front. Biosci. 2003, 8, d222-d237. [CrossRef] 
29. Wang, Y.; Chan, S.; Tsang, B.K. Involvement of inhibitory nuclear factor-kappaB (NFkappaB)-independent NFkappaB activation in the gonadotropic regulation of $X$-linked inhibitor of apoptosis expression during ovarian follicular development in vitro. Endocrinology 2002, 143, 2732-2740. [CrossRef]

30. Vasudevan, K.M.; Gurumurthy, S.; Rangnekar, V.M. Suppression of PTEN expression by NF-kappa B prevents apoptosis. Mol. Cell Biol. 2004, 24, 1007-1021. [CrossRef]

31. Simon, P.S.; Sharman, S.K.; Lu, C.; Yang, D.; Paschall, A.V.; Tulachan, S.S.; Liu, K. The NF-kappaB p65 and p50 homodimer cooperate with IRF8 to activate iNOS transcription. BMC Cancer 2015, 15, 770. [CrossRef] [PubMed]

32. Scholzen, T.; Gerdes, J. The Ki-67 protein: From the known and the unknown. J. Cell Physiol. 2000, 182, 311-322. [CrossRef]

33. Uri-Belapolsky, S.; Miller, I.; Shaish, A.; Levi, M.; Harats, D.; Ninio-Many, L.; Kamari, Y.; Shalgi, R. Interleukin 1-alpha deficiency increases the expression of Follicle-stimulating hormone receptors in granulosa cells. Mol. Reprod. Dev. 2017, 84, 460-467. [CrossRef] [PubMed]

34. Pelusi, C.; Ikeda, Y.; Zubair, M.; Parker, K.L. Impaired follicle development and infertility in female mice lacking steroidogenic factor 1 in ovarian granulosa cells. Biol. Reprod. 2008, 79, 1074-1083. [CrossRef] [PubMed]

35. Sudo, H.; Minami, A. Regulation of apoptosis in nucleus pulposus cells by optimized exogenous Bcl-2 overexpression. J. Orthop. Res. 2010, 28, 1608-1613. [CrossRef] [PubMed]

36. Liu, H.; Xu, G.; Yuan, Z.; Dong, Y.; Wang, J.; Lu, W. Effect of kisspeptin on the proliferation and apoptosis of bovine granulosa cells. Anim. Reprod. Sci. 2017, 185, 1-7. [CrossRef]

37. Bildik, G.; Akin, N.; Seyhan, A.; Esmaeilian, Y.; Yakin, K.; Keles, I.; Balaban, B.; Ata, B.; Urman, B.; Oktem, O. Luteal granulosa cells from natural cycles are more capable of maintaining their viability, steroidogenic activity and LH receptor expression than those of stimulated IVF cycles. Hum. Reprod. 2019, 34, 345-355. [CrossRef]

38. Chen, Z.; Lei, L.; Wen, D.; Yang, L. Melatonin attenuates palmitic acid-induced mouse granulosa cells apoptosis via endoplasmic reticulum stress. J. Ovarian Res. 2019, 12, 43. [CrossRef]

39. Lei, L.; Han, F.; Cui, Q.; Liao, W.; Liu, H.; Guan, G.; Yang, L. IRS2 depletion inhibits cell proliferation and decreases hormone secretion in mouse granulosa cells. J. Reprod. Dev. 2018, 64, 409-416. [CrossRef]

40. Zhu, W.; Yang, M.; Shang, J.; Xu, Y.; Wang, Y.; Tao, Q.; Zhang, L.; Ding, Y.; Chen, Y.; Zhao, D.; et al. MiR-222 inhibits apoptosis in porcine follicular granulosa cells by targeting the THBS1 gene. Anim. Sci. J. 2019, 90, 719-727. [CrossRef]

41. Lobach, V.N.; Casalechi, M.; Dela Cruz, C.; Pereira, M.T.; Del Puerto, H.L.; Reis, F.M. Caspase-3 gene expression in human luteinized granulosa cells is inversely correlated with the number of oocytes retrieved after controlled ovarian stimulation. Hum. Fertil. 2019, 22, 33-38. [CrossRef] [PubMed]

42. Makker, A.; Goel, M.M.; Mahdi, A.A. PI3K/PTEN/Akt and TSC/mTOR signaling pathways, ovarian dysfunction, and infertility: An update. J. Mol. Endocrinol. 2014, 53, R103-R118. [CrossRef] [PubMed]

43. Zheng, W.; Nagaraju, G.; Liu, Z.; Liu, K. Functional roles of the phosphatidylinositol 3-kinases (PI3Ks) signaling in the mammalian ovary. Mol. Cell Endocrinol. 2012, 356, 24-30. [CrossRef] [PubMed]

44. Furlong, H.C.; Stampfli, M.R.; Gannon, A.M.; Foster, W.G. Cigarette smoke exposure triggers the autophagic cascade via activation of the AMPK pathway in mice. Biol. Reprod. 2015, 93, 93. [CrossRef]

45. Xin, X.; Li, Z.; Zhong, Y.; Li, Q.; Wang, J.; Zhang, H.; Yuan, X.; Li, J.; Zhang, Z. KISS1 Suppresses Apoptosis and Stimulates the Synthesis of E2 in Porcine Ovarian Granulosa Cells. Anim. (Basel) 2019, 9. [CrossRef]

46. Liu, Z.; Castrillon, D.H.; Zhou, W.; Richards, J.S. FOXO1/3 depletion in granulosa cells alters follicle growth, death and regulation of pituitary FSH. Mol. Endocrinol. 2013, 27, 238-252. [CrossRef]

47. Yamamoto, H.; Yamashita, Y.; Saito, N.; Hayashi, A.; Hayashi, M.; Terai, Y.; Ohmichi, M. Lower FOXO3 mRNA expression in granulosa cells is involved in unexplained infertility. J. Obs. Gynaecol. Res. 2017, 43, 1021-1028. [CrossRef]

48. Huang, L.; Wang, Z.B.; Jiang, Z.Z.; Hu, M.W.; Lin, F.; Zhang, Q.H.; Luo, Y.B.; Hou, Y.; Zhao, Y.; Fan, H.Y.; et al. Specific disruption of Tsc1 in ovarian granulosa cells promotes ovulation and causes progressive accumulation of corpora lutea. PLoS ONE 2013, 8, e54052. [CrossRef] 
49. Guo, J.; Zhang, T.; Guo, Y.; Sun, T.; Li, H.; Zhang, X.; Yin, H.; Cao, G.; Yin, Y.; Wang, H.; et al. Oocyte stage-specific effects of MTOR determine granulosa cell fate and oocyte quality in mice. Proc. Natl. Acad. Sci. USA 2018, 115, E5326-E5333. [CrossRef]

50. Kim, J.H.; Kim, Y.H.; Kim, H.M.; Park, H.O.; Ha, N.C.; Kim, T.H.; Park, M.; Lee, K.; Bae, J. FOXL2 posttranslational modifications mediated by GSK3 beta determine the growth of granulosa cell tumours. Nat. Commun. 2014, 5. [CrossRef]

(C) 2019 by the authors. Licensee MDPI, Basel, Switzerland. This article is an open access article distributed under the terms and conditions of the Creative Commons Attribution (CC BY) license (http://creativecommons.org/licenses/by/4.0/). 